\title{
Preparation of an inactivated penta cell culture vaccine against canine distemper, canine parvo, canine hepatitis "canine adeno-1", canine adeno-2 and rabies viruses for dogs
}

\author{
Naglaa I. Aly, Zeinab T. S. Salama \\ Veterinary Serum and Vaccine Research Institute, Abbassia, P.O.B.131, Cairo, Egypt
}

\begin{abstract}
A penta-dog inactivated cell culture vaccine was prepared to protect dogs against canine distemper virus, canine parvovirus, canine adenovirus1, 2 and rabies virus. The potency of this vaccine was compared with that of single inactivated vaccines prepared against each disease, in different groups of susceptible dogs. It was found that the protective dose of penta-dog vaccine $(2 \mathrm{ml})$ including the protective amounts of the five viral proteins resulted in full protection of vaccinated dogs against the challenge with virulent strain of the used viruses showing no antagonizing effect between each other with and no adverse postvaccinal reaction. So, the prepared inactivated cell culture penta-dog vaccine is a safe and potent vaccine for dogs which resulted in saving time, cost, and effort stress factors on animals and providing good immune statues.
\end{abstract}

Dogs seem to be special animal species characterized by many favorable characters as intelligence and faithful making an important bound of friendship exist between people and their pets (Greene, 1998) but dogs mostly represent a dangerous source of zoonotic viral diseases as rabies, canine distemper and infectious canine hepatitis (Gaskell and Bennett, 1996 and Macpherson et al., 2000).

Rabies as a major zoonotic disease has a considerable public health, veterinary and economic impact. It is an acute fatal viral encephalomyelitis disease, caused by a filterable virus that belongs to family Rhabdoviridae group (Hummeler et al., 1968). Transmission of rabies occurs by bits of infected carnivores (Williams and Barker, 2001). There is no measure has been helped in reduction of human rabies as effectively as the widespread vaccination of the domestic dog population.

Canine distemper was placed beside rabies as diseases causing the highest fatality among dogs and other wild carnivores (Appel and Montali, 1994). The disease is characterized by respiratory, gastro-intestinal and central nervous manifestations (Craig, 1998). The disease was recognized among infants causing severe respiratory diseases, fever and death (Smith and Lauffer 1962) and in adult human making a chronic inflammatory bone disorder "Paget's disease" (Cartwright et al., 1993 and Reddy et al., 1996). The disease is caused by a virus belongs to genus Morbilivirus belonged to family Paramyxoviridae (Sashi and Dutla, 1981).

Canine parvo is a highly contagious viral disease affecting dogs characterized by bloody diarrhea, vomiting, and emaciation that usually ends with death especially in young puppies (Johnny, 1998). This disease constituted a serious problem among military dogs as recorded by (Abd-El Ghany, 1988). The disease is caused by a virus related to Parvoviridae family (Apple and Gillespie, 1972).

Infectious canine hepatitis (ICH) or Rubath's disease is a serious disease characterized by respiratory, ocular disease, encephalopathy, chronic hepatitis and interstitial nephritis (Greene, 1998). This disease is caused by canine adenovirus type-1 (CAV-1).

Kennel cough or infectious larngotrachitis was described as an acute contagious respiratory infectious disease of dogs characterized by sudden onset, paroxymal cough with variable expectoration and naso-ocular discharge (Richard and Shelly, 1998). This disease is caused by canine adenovirus type-2 (CAV-2). CAV-1 and CAV-2 are two viruses belong to family Adenoviridae and they have worldwide serologic homogenicity as well as immunologic similarities to human adenoviruses (Carmicheal and Barnes, 1961; Greene, 1998 and Benko et 
al., 1999).

Vaccination has proved itself over the past 120 years to be the most efficient and cost effective method for controlling the infectious diseases (Tizard, 2000 and Stephenson, 2001). Since, immunization remains the most practical and cost effective way to prevent many infectious diseases, the development of additional multidisease combination vaccines may lead to increased rates of immunization and thereby population-wide control of such diseases. Greene (1998) mentioned that separate vaccine products may result in exposure to more extraneous protein and allergenic components than using the same antigen in combinations. Because of convenience of mixed vaccines, it has become common to employ mixture of organisms in a single form.

This study aimed to prepare and evaluate the efficacy of a locally prepared combined inactivated penta-dog vaccine (Rabies, CDV, CPV, CAV-1 and CAV-2). The efficacy of this vaccine was investigated through the estimation of the induced immunity in puppy's sera and challenge of vaccinated animals with virulent virus strains.

Animals.

\section{Material and Methods}

Mice. 150 weaned albino Swiss mice were used to test the safety and potency of the prepared vaccine where each mouse was inoculated intrapretonialy with $0.5 \mathrm{ml}$ of the vaccine to detect the relative potency of rabies virus in the prepared vaccine.

Puppies. The present work was applied on 47 puppies of local breed aged (3-5 months). All of them were screened for using rabies, $\mathrm{CD}, \mathrm{CP}$, CAV-1 and CAV-2 antibodies VNT.

Five of theses puppies were used for the safety tests of the prepared vaccines according to European pharmacopoeia (2001) and the other puppies were used in vaccination trial.

Viruses.

Vaccinal strains.Standard cell culture adapted rabies virus strain (ERA) propagated on BHK21 cell line (Edris, 1994), Canine distemper virus (CD) (Guriguis, 1991) Canine parvovirus $\left(\mathrm{CPV}_{39}\right)$ (Attyat, 1994), a local isolate of live attenuated canine adenovirus type-1 (CAV-1) (Khodier et al., 2003) and canine adenovirus type-2 "CAV-2" (Guriguis et al., 2003) propagated on vero cell line were used for preparation of penta dog vaccine and serum neutralization test. The infectivity titers of these viruses were $10^{8}, 10^{7}, 10^{7.5}, 10^{6.5}$ and $10^{7}$ $\mathrm{CCID}_{50} / \mathrm{ml}$ respectively. All virus strains were supplied from the Dept. of Pet Animal Vaccine Research; Veterinary Serum and Vaccine Research Institute, Abbassia, Cairo, Egypt.

Virulent strains. A challenge rabies virus strain (CVS) propagated in mice brain of a titer $10^{7} \mathrm{MICLD}_{50} / \mathrm{ml}$ (Mouse Intracerebral lethal dose) was used in the test of National Institute of Health (NIH) according to (Wilbur and Aubert, 1996). Standard Synder Hill virulent CDV propagated on embryonated chicken egg of a titer $10^{5} \mathrm{EID}_{50} / \mathrm{ml}$, virulent stain of CPV of a titer $10^{3.5} \mathrm{TCID}_{50} / \mathrm{ml}$ propagated 3 passages in Norden laboratory feline kidney cell culture (NLFK) and virulent strain of the local isolates of CAV-1 and CAV-2 of a titer of $10^{5}, 10^{4.7}$ $\mathrm{TCID}_{50} / \mathrm{ml}$ respectively were used in the challenge test of the vaccinated dogs. Also these strains were supplied by the same department.

Local vaccines. Single inactivated cell culture rabies, $\mathrm{CD}, \mathrm{CP}, \mathrm{CAV}-1$ and $\mathrm{CAV}-2$ were supplied by The Dept. of Pet Animal Vaccine Research.

Virus titration. Rabies, CDV, CPV, CAV-1 and CAV-2 viruses were titerated in the corresponding cell cultures using the microtitre technique according to (Trimarchi et al., 1996) and the virus titer was calculated according to (Reed and Muench, 1938).

Preparation of the inactivated penta dog vaccine.Each virus batch was titerated and tested separately for freedom from foreign contaminants (aerobic and anaerobic bacteria, fungi and Mycoplasma). Each virus batch was subjected to the inactivation process according to (Edris, 1994) for rabies, (Aly, 2001) for CDV, (Koteb et al., 1998) for CPV and (Guriguis et al., 2003 and Guriguis, 2004) for CAV-1 and CAV2 using binary ethylelimine (BEI) as an inactivating agent at a final concentration of $0.01 \mathrm{M}$. Sodium thiosulphate ( $20 \%$ solution) was used as stopping reagent in concentration of $2 \%$. The combined vaccine was prepared by mixing the five inactivated viruses in a manner ensuring that each $2 \mathrm{ml}$ of the final mixture contains the protective doses of each virus depending on the amount of viral protein, which previously determined by (Edris et al., 2001, Guriguis et al., 2003 and Koteb and Daoud 2004). Alhydragel was added as adjuvant in the ratio of $20 \%$ as mentioned by (Salama et al., 2003 and Koteb and Daoud 2004).

Determination of the viral antigen protein. 
The viral antigen protein was estimated for each virus used in preparation of the penta dog vaccine according to (Weichselbaum, 1946).

Quality control tests. The prepared penta dog vaccine was subjected to examination of its freedom from foreign contaminants, safety and potency following the recommendations of FAO (1994) and European pharmacopoeia (2001). Special test was applied for rabies vaccine as a safety and potency test in weaned mice following the National Institute of Health (NIH) according to (Wilbur and Aubert, 1996) who recommended that the relative potency of the inactivated rabies vaccines should not be less than 0.3 .

Vaccination trial. Forty two dogs were divided into 3 groups and used in the vaccination trial as follow: Group 1 (15) dogs were subdivided into five subgroups (3 dogs /group) where each subgroup was vaccinated with one of the single vaccine of rabies, $\mathrm{CDV}, \mathrm{CPV}, \mathrm{CAV}-1$ or $\mathrm{CAV}-2$ vaccines, Group 2 consisted of 15 dogs that vaccinated with the prepared inactivated penta dog vaccine in a dose of $2 \mathrm{ml} / \mathrm{dog}$ by $\mathrm{s} / \mathrm{c}$ route. Four weeks post vaccination twelve dogs were subdivided into four subgroups (3 dogs/ group) where each one of these groups was challenged with one of the virulent virus strains of CDV or CPV or CAV-1 or CAV-2.Four subgroups of group (1) were treated in the same manner. Group 3 consisted of 12 dogs, was kept without vaccination as control. On challenge time these dogs were subdivided into four subgroups (3 dogs/ group) where each subgroup was challenged with one the virulent virus strains. Each animal group was kept separately in individual kennels under hygienic measure receiving balanced diet and adequate water. Serum samples were obtained weekly from all animal groups, to estimate the titer of induced antibodies.

Virus neutralization test. VNT was carried out to estimate the titer of neutralizing antibodies in vaccinated puppies using the microtitre technique according to (Bass et al., 1982).

Challenge test. To test the potency of the inactivated prepared penta dog vaccine, the vaccinated and control puppies were challenged against CDV, CPV, CAV-1 and CAV-2 through the oronasal route according to (Guriguis et al.,
2003; Khodier et al., 2003; Koteb and Daoud, 2004 and Guriguis, 2004). Challenge against rabies was included in the NIH test where it is forbidden to be carried out in dogs.

\section{Results and Discussion}

Veterinary vaccinology is a very interesting and rapidly developing field. In fact, veterinary vaccines are not only used for prevention of infectious diseases in the animal health sector but also help to solve problems of public health via reducing detrimental environmental impact of using some veterinary drugs preventing emergence of resistance of micro-organisms or parasites (Pastoret and Falize, 1999)

Since immunization remains the most practical and cost effective way to prevent many infectious diseases, the development of additional multidisease combined vaccines may lead to increased rates of immunization and thereby population-wide control of such diseases (Ronald, 1999).

Depending on the safety of inactivated vaccines in addition to their easy to be given at any age, such vaccines become of choice as recorded by (Olson et al., 1988; Cooper et al., 1991 and Miyamoto et al., 1995).

So the present study was designed to prepare an inactivated penta-dog combined vaccine against the most important viral diseases of dogs including rabies, $\mathrm{CD}, \mathrm{CP}, \mathrm{ICH}$ and Kennel cough.

BEI was the inactivating agent of choice where it suppresses the infectivity of viruses by cross link of the nucleic acid chains, leaving their antigenic structure and viral protein unaffected; hence it does not interfere with their antigenicity (Mowat and Rweyemamu, 1997 and Tizard, 2000). The inactivation process was done by using 3\% BEI of $0.01 \mathrm{M}$ concentration at $37^{\circ} \mathrm{C}$ till complete inactivation which was obtained after $5,7,8,8$ and $8 \mathrm{~h}$ for rabies, CDV, CPV, CAV-1 and CAV-2 respectively (Koteb and Douad, 2004 and Guirgius, 2004). Also the used percentage of the alhydragel was used as determined by same authors.

For testing the efficacy of the inactivated single and penta-dog vaccine, the amount of the antigenic viral proteins were determined. As shown in (Table 1), values were found to be similar to those obtained by (Bradford, 1976; Saleh et al., 2002; Koteb and Douad, 2004 and Guirgius, 2004) and confirmed by that obtained by (Tizard, 2000) who mentioned that a greater antigenic mass must be present in the inactivated vaccines. 
Table (1): Antigenic viral protein in the prepared vaccines.

\begin{tabular}{lc}
\hline \multicolumn{1}{c}{ Tested Vaccine } & Antigenic viral protein $\boldsymbol{\mu g} / \mathbf{m l}$ \\
\hline Single Rabies vaccine & 12.5 \\
Single CDV vaccine & 12.2 \\
Single CPV vaccine & 12.1 \\
Single CAV-1 vaccine & 12.0 \\
Single CAV-2 vaccine & 12.1 \\
Total viral protein in the combined form & 60.7 \\
\hline
\end{tabular}

Table (2): Relative potency of rabies virus vaccines as detected by NIH.

\begin{tabular}{lc}
\hline \multicolumn{1}{c}{ Tested vaccine } & Relative potency \\
\hline Single inactivated rabies tissue culture vaccine & 2.2 \\
Penta-dog inactivated vaccine & 2.0 \\
\hline
\end{tabular}

Table (3) Potency of single and penta-dog prepared vaccines.

\begin{tabular}{|c|c|c|c|c|}
\hline Type of Tested vaccine & $\begin{array}{c}\text { No. of } \\
\text { vaccinate } \\
\text { d puppies }\end{array}$ & $\begin{array}{c}\text { Used } \\
\text { challenge } \\
\text { virus }\end{array}$ & $\begin{array}{c}\text { No. of } \\
\text { survived } \\
\text { puppies }\end{array}$ & Observed signs \\
\hline CD vaccine & 3 & CDV & 3 & \multirow{4}{*}{$\begin{array}{c}\text { No } \\
\text { Clinical } \\
\text { Signs }\end{array}$} \\
\hline CP vaccine & 3 & CPV & 3 & \\
\hline ICH vaccine & 3 & CAV-1 & 3 & \\
\hline Kennel cough vac. & 3 & CAV-2 & 3 & \\
\hline \multirow{4}{*}{ Penta-dog vaccine } & 3 & CDV & 3 & \multirow{4}{*}{$\begin{array}{c}\text { No } \\
\text { Clinical } \\
\text { Signs }\end{array}$} \\
\hline & 3 & $\mathrm{CPV}$ & 3 & \\
\hline & 3 & CAV-1 & 3 & \\
\hline & 3 & $\mathrm{CAV}-2$ & 3 & \\
\hline \multirow{4}{*}{$\begin{array}{c}\text { Control } \\
\text { Non vaccinated }\end{array}$} & 3 & $\mathrm{CDV}$ & 0 & \multirow{4}{*}{$\begin{array}{c}\text { Ocular and nasal discharge, fever } \\
\text { then recovered } \\
\text { Fever, enteritis, depression and death } \\
7 \text { days later } \\
\text { Depression, fever, ocular opacity } \\
\text { and death after } 10 \text { days } \\
\text { Depression, fever, severs respiratory } \\
\text { signs and death. }\end{array}$} \\
\hline & 3 & $\mathrm{CPV}$ & 0 & \\
\hline & 3 & CAV-1 & 0 & \\
\hline & 3 & CAV-2 & 0 & \\
\hline
\end{tabular}

Table (4): Neutralizing antibody titers in vaccinated puppies with single and penta-dog vaccine.

\begin{tabular}{|c|c|c|c|c|c|c|c|c|c|c|}
\hline \multirow{3}{*}{$\begin{array}{l}\text { Week post } \\
\text { vaccination }\end{array}$} & \multicolumn{10}{|c|}{ Neutralizing Antibody titer in vaccinated puppies $\left(\log _{10}\right)$} \\
\hline & \multicolumn{2}{|c|}{ RABIES } & \multicolumn{2}{|c|}{ CDV } & \multicolumn{2}{|c|}{ CPV } & \multicolumn{2}{|c|}{ CAV-1 } & \multicolumn{2}{|c|}{ CAV-2 } \\
\hline & $\begin{array}{l}\text { Single } \\
\text { Vaccine } \\
\end{array}$ & $\begin{array}{l}\text { Penta-dog } \\
\text { Vaccine } \\
\end{array}$ & $\begin{array}{l}\text { Single } \\
\text { Vaccine } \\
\end{array}$ & $\begin{array}{l}\text { Penta-dog } \\
\text { Vaccine }\end{array}$ & $\begin{array}{l}\text { Single } \\
\text { Vaccine }\end{array}$ & $\begin{array}{l}\text { Penta-dog } \\
\text { Vaccine } \\
\end{array}$ & $\begin{array}{l}\text { Single } \\
\text { Vaccine }\end{array}$ & $\begin{array}{l}\text { Penta-dog } \\
\text { Vaccine } \\
\end{array}$ & $\begin{array}{l}\text { Single } \\
\text { Vaccine }\end{array}$ & $\begin{array}{l}\text { Penta-dog } \\
\text { Vaccine }\end{array}$ \\
\hline $0 \mathrm{WPV}^{*}$ & 0 & 0 & 0 & 0 & 0 & 0 & 0 & 0 & 0 & 0 \\
\hline $1 \mathrm{WPV}$ & 0.32 & 0.3 & 0.3 & 0.3 & 0.6 & 0.65 & 0.3 & 0.3 & 0.4 & 0.3 \\
\hline $2 \mathrm{WPV}$ & 0.75 & 0.7 & 0.9 & 0.95 & 1.2 & 1.3 & 0.5 & 0.6 & 0.6 & 0.6 \\
\hline 3 WPV & 1.3 & 1.2 & 1.3 & 1.4 & 1.5 & 1.5 & 0.7 & 0.9 & 1.2 & 1.2 \\
\hline \multirow{2}{*}{$4 \mathrm{WPV}$} & \multirow[b]{2}{*}{1.7} & \multirow{2}{*}{1.6} & 1.7 & 1.8 & 1.8 & 1.9 & 1.2 & 1.2 & 1.8 & 1.9 \\
\hline & & & \multicolumn{2}{|c|}{ Challenge } & \multicolumn{2}{|c|}{ Challenge } & \multicolumn{2}{|c|}{ Challenge } & \multicolumn{2}{|r|}{ Challenge } \\
\hline $5 \mathrm{WPV}$ & 1.9 & 1.8 & 0.8 & 0.9 & 1.7 & 1.8 & 1.1 & 1.0 & 1.5 & 1.6 \\
\hline $6 \mathrm{WPV}$ & 2.0 & 1.9 & 1.5 & 1.7 & 2.2 & 2.3 & 1.5 & 1.5 & 1.8 & 1.8 \\
\hline $8 \mathrm{WPV}$ & 2.0 & 2.0 & 1.8 & 1.9 & 2.2 & 2.3 & 1.8 & 1.9 & 2.2 & 2.1 \\
\hline $12 \mathrm{WPV}$ & 2.0 & 2.0 & 1.8 & 2.0 & 2.2 & 2.3 & 1.9 & 1.9 & 2.3 & 2.3 \\
\hline $16 \mathrm{WPV}$ & 2.0 & 2.0 & 1.8 & 2.0 & 2.1 & 2.3 & 1.9 & 1.9 & 2.3 & 2.3 \\
\hline
\end{tabular}

$* \mathrm{WPV}=$ Week post vaccination. 
The prepared single and penta-dog vaccines were found to be free from foreign contaminants (aerobic and anaerobic bacteria, fungi and mycoplasma), safe in both mice and dogs where there was no adverse reaction or any reaction at the vaccination site. To avoid public health hazard, testing the potency of the inactivated rabies vaccine in the single and penta-dog vaccines was carried out through the NIH test which showed that the relative potency was 2.2 and 2 for single and penta-dog vaccines respectively. These values were found to be higher than the value recommended by (Larghi and Nebel, 1980 and Wilbur and Aubert, 1996) who mentioned that the relative potency of the inactivated rabies vaccine should not be less than 0.3 . On the other hand, immunization of dogs with these vaccines should provide a good prolonged immunity as established by (Sikes et al., 1971 and Larghi and Nebel, 1980) who used a rabies vaccine of antigenic value 20 times greater than the minimum required dose of $\mathrm{NIH}$ providing $90 \%$ protection in vaccinated dogs up to 3 years. So the prepared vaccines could provide a protection for dogs not less than one year.

Concerning the potency test of CDV, CPV, CAV-1 and CAV-2; it was found that full protection $(100 \%)$ was obtained in all vaccinated dogs with the single and penta-dog vaccines upon challenge with the corresponding virulent strain, while non vaccinated dogs showed typical symptoms of CD (Ocular and nasal discharge, fever then recovered), CP (fever, enteritis, depression and death 7 days later), CAV-1 (depression, fever, ocular opacity and death after 10 days) and CAV-2 (depression, fever, severs respiratory signs and death). These symptoms (Table 3) were similar to those mentioned by (Green, 1998). Symptoms of paralysis were appeared in control mice in potency test (NIH) for rabies vaccine.

The results of the potency test correlated to the results of virus neutralization test (Table 4) which revealed that detectable levels of the antibodies appear from the first week post vaccination and reached good levels within four weeks in both single and penta-dog vaccines. These levels of antibodies protected animals against challenge with virulent viruses and came in agreement with (CFR, 1997) that recommended serum neutralizing titer not less than $1: 50\left(1.7 \log _{10}\right)$ for the CD; $1: 16\left(1.2 \log _{10}\right)$ for CP and 1:10 for Canine adeno type 1 and 2 .
The obtained results also agreed with (Sprino and Harris, 1983; Guirguis, 1991; Miyamoto et al., 1995; Khodier et al., 1998 and Edries et al., 2001) who reported that dogs were considered immune to canine distemper if their antibody titer was higher than 30 , while in canine parvo, titer of 8 is protective against clinical disease and intestinal replication of virulent virus as mentioned by (Ruth and Emery, 1981 and Ackermann et al., 1983), on the other side, (Fiscus et al., 1985) consider neutralizing titer of 16 is protective. In addition regarding canine adeno type 1 and 2 any increase in serum neutralizing antibodies titers could be considered protective as mentioned by (Cooper et al., 1991 and Castro and Heuschele, 1992). Regarding rabies vaccine, the obtained results also agreed with that obtained by (Sikes et al., 1971 and Arnold and Salvatierra, 1974) who reported that serum neutralizing level of 1:5 or greater was protective against rabies infection. These results indicated that all currently used single vaccines were safe and potent inducing good levels of specific antibodies (Bass et al., 1982; Sprino and Harris, 1983; O'Brien et al., 1986 and Cooper et al., 1995).

The penta-dog vaccine was as immunologically as single vaccine indicating that there was no antagonizing effect between the individual antigens in the combined penta-dog vaccine as similar titers of antibodies against both of CD, CP, CAV-1, CAV-2 and rabies were obtained in both single and penta vaccines. These finding confirmed by results obtained by (Gorski, 1975; Ackermann et al., 1983; Sprino and Harris, 1983; Olson et al., 1988; Cooper et al., 1995; Miyamato et al., 1995; Khodier et al., 1998; Koteb et al., 1998; Hamoda et al., 2000; Edries et al., 2001 and Saleh et al., 2002; Attyat and Douad, 2004 and Guirgius, 2004). Finally it could be concluded that, the used vaccines either in single or penta form were safe and potent and can protect dogs against the five diseases.

\section{References}

Abd El-Ghany, M. (1988): Studies on parvovirus in dogs. MVSc. Thesis (Microbiology), Cairo Univ., Egypt.

Ackerman, O.; Stegman, H. and Jaeger, O. (1983): Simultaneous immunization of dogs against parvovirus, distemper, rabies, contagious hepatitis and leptospirosis. Blauen Hefte Furdentierazt., 67:302-308.

Aly, N. I. (2001): Studies on the preparation of an inactivated canine distemper vaccine. Ph.D. Thesis. (Microbiol.) Fac. Vet. Med. Cairo Univ., Egypt.

Appel, M. J. and Montali, R. J. (1994): Canine distemper and emerging disease in exotic species. Amer. Ass. Zoo. Vet. pp. 22-27. 
Appel, M. J. and Gillespie, J. E. (1972): Canine distemper monograph. in: S. Gard, C. Hallauer and K.F. Meyer (eds.) Handbook of virus Res. Springer-verlag. N.Y. pp. 34-63.

Arnold, R. M. and Salvatierra, J. (1974): Immunity against paralytic rabies in cattle following vaccination with ERA vaccine under ranch conditions in Bolivia. Part IV five-year post vaccination studies. Trop. Anim. Health Prod. 6(4): 199-201.

Bass, E. P.; Gill, M. A. and Beckenhaner, W. H. (1982): Development of a modified live canine origin parvovirus. J. Am. Vet. Med. Assoc., 181 (9): 909-913.

Benko, M.; Harrach, B. and Russel, W. C. (1999): Virus taxonomy. The report of Int. Committee on taxonomy of viruses. Acadamic press N.Y. pp.227-238.

Bradford, M. M. (1976): A rapid and sensitive method for the quantitation of micrograms quantities of protein utilizing the principle or protein-dye binding. Anal. Biochem., 72: 248-252.

Carmichael, L. E. and Barnes, F. D. (1961): Serological comparison between infectious canine hepatitis virus and human adenovirus types. P. S. E. B. M. 107: 214-218.

Castro, A. and Heuschele, W. P. (1992): Veterinary Diagnostic Virology. Mosby Year Book.

Cartwright E. J., Gordon M. T., Freemont A. J. (1993): Paramyxoviruses and Paget's disease. J. Med. Virol., 40: 133-141.

CFR (1997): Code American Federal Regulation. Evaluation of pet animal vaccine. 9CFR. pp.598-601.

Cooper, P. E.; Chappuis, G.; Saint Gerand, A. L. and Duret (1991): Comparison de L'efficacite des different vaccines du evaluation les responses serologiques et après epruves virulentes. 12,72 et 26 moisapres vaccination. Bulletin Mensuei de la Societe Veterinaire Pratique de France, 75: 131-152.

Cooper, P. E.; Chappuis, G.; Saint, G .A. and Duret, C. (1995): Comparison of monovalent and polyvalent vaccines indogs against canine adeno- and parvovirus infections and rabies. Med. Vet. 12: (5) 341-347.

Craig, E. G. (1998): Infectious diseases of dog \& cat. Canine distemper Second Edition W.B. Saunders companyAdivision of Harcourt Brace and company Philadephia, London, Toronto, Montreal, Sydney, Tokyo. pp. 9-22.

Edris, S. M. (1994): Studies on preparation of inactivated tissue culture antirabies vaccines. Ph.D. Thesis. (Microbiol.) Fac. Vet. Med. Cairo Univ., Egypt.

Edris, S. M; Guirguis, W. I.; Khodier, M. H. and Koteb, A. M. (2001): Preparation of a combined vaccine against canine distemper and rabies. $2^{\text {nd }}$ Sci. Cong. Fac. Vet. Med. Beni-Suef, Egypt.

European pharmacopoeia (2001): $3^{\text {rd }}$ ed. council of Europe. pp. 545-547.

FAO (1994): Quality control of rinderpest cell culture vaccine. Standard operating procedures. FAO, report No.118

Fiscus, S. A.; Mildbrand, M. M.; Gordonf, C. and Scott, W. (1985): Rapid enzyme linked immunosorbent assay for detecting antibodies to canine parvovirus. Am. J. Vet. Res., 46 (4): 859-863.

Gaskell, R. M. and Bennett, M. (1996): Feline and canine infectious diseases. Blackwell Sci. Inc., USA, 111-117.

Gorski, J. (1975): Antibody formation and resistance in dogs vaccinated intravenously and subcutaneously against distemper and Rubarth's disease. Pol. Arch. Weter., 18 (1): 23-34.

Greene, C. E. (1998): Infectious diseases of the dog and cat. Canine immunization recommendations. W.B. Saunders Company, Philadelphia, USA. pp.751
Greene, C. E. (1998): Infectious diseases of the dog and cat. Infectious canine hepatitis. W. B. Saunders Company, Philadelphia, USA. pp. 22-26.

Guirguis, W. I. (1991): Trials for preparation of a vaccine against canine distemper. Ph.D. Thesis. (Microbiol.) Fac. Vet. Med. Cairo Univ., Egypt.

Guirguis, W. I. (2004): Studies on the cross protection between canine hepatitis (Adeno-1) and (Adeno-2) viruses in dogs. $1^{\text {st }}$ Inter. Conf. Vet. Res. Div., NRC, Cairo, Egypt. pp. 106-112.

Guirguis, W. I.; Koteb, A. M.; and Daoud, A. M. (2003): Preparation of an inactivated canine hepatitis vaccine. J. Egypt. Vet. Med. Assoc., 63 (1): 343-356.

Hamoda, F. K.; El-Gallad, S. B.; Koteb, A. M.; Edries, S. M; Saleh, A. A. and Guirguis, W. I. (2000): Studies on the simultaneous vaccination of dogs with some pet animal vaccines. J. Vet. Med., Giza. 48 (4): 647-657.

Hummeler, K.; Tomassini, N.; Sokol, K.; Kuwert, F. and Koprowski, H. (1968): Morphology of nucleoprotein component of rabies virus. J. Virol., 2:1191-1194.

Johnny, D. H. (1998): Canine viral enteritis, Infectious diseases of $\operatorname{dog} \&$ cat. Canine viral enteritis Second Edition W. B. Saunders company- A division of Harcourt Brace and company Philadelphia, London, Toronto, Montreal, Sydney, Tokyo.pp.40-48.

Khodier, M. H; Koteb, A. M.; Guirguis, W. I.; and Habashi, Y. Z. (1998): Preparation of a bivalent vaccine against canine distemper and canine parvovirus. $4^{\text {th }}$ Vet. Med. Zag. Cong., Egypt, 152-160.

Khodier, M. H.; Koteb, A. M.; Saleh, A. A.; Guirguis, W. I. and Daoud, A. M. (2003): Studies on canine hepatitis in Egypt, 2- preparation of a live attenuated vaccine. $3^{\text {rd }}$ Sci. Conf. Vet. Med., Fact. Vet. Med. Mansoura Univ., Egypt. pp. 317-328.

Koteb A. M. (1994): Studies on preparation of canine parvovirus vaccine. Ph.D. Thesis. Microbiol. Fac. Vet. Med. Cairo Univ., Egypt.

Koteb, A. M.; Zaki, H. Y. and Sami, S. M. (1998): Studies on production of an inactivated canine parvovirus vaccine. $4^{\text {th }}$ Vet. Med. Zag. Cong. Egypt .pp. 240-247.

Koteb, A. M. and A. M. Douad (2004): Tetravalent dog vaccine (A vaccine against canine distemper, canine parvo, canine hepatitis and rabies). The $1^{\text {st }}$ Int. Conf. Vet. Res.Div., NRC, Cairo, Egypt. pp.74-85.

Larghi, O. P. and Nebel, A. E. (1980): Rabies virus inactivation by binary ethylenimine; new method for inactivated vaccine production J. Clin. Microbiol., 2:120122

Macpherson, C. N.; Meslin, F.X. and Wandeler, A.I. (2000): Dogs zoonoses and public health. CABI publishing 63-82.

Miyamoto; Taura, Y.; Une, S.; Yoshitaka, M. Nakama and Watanobe, S. (1995): Immunological response to polyvalent canine vaccines to dogs. J. Vet. Med. Sci., 57 (2): 347.

Mowat, N. and Rweyemamu (1997): Vaccine: the production and quality control of veterinary vaccines for use in developing countries. FAO, U.N.

O'brien, S. E.; Roth, J. A. and Hill, B. L. (1986): Response of puppies to modified-live canine parvo component in a combined vaccine. J. Am. Vet. Med. Assoc. 188 (7): 899-901.

Olson, P.; Klingeborn, B. and Hedhammer, A. (1988): Serum antibody response to canine parvovirus, canine adenovirus-1 and canine distemper virus in dogs with known status of immunization. Am. J. Vet. Res., 49 (9): $1460-1466$ 
Pastoret, P. P. and Falize, F. (1999): Viral Veterinary vaccines. Dev. Biol. Stand., 101:73-78.

Reddy, S. V.; Singer, F. R. and Mallette, L. M. (1996): Detection of measles virus nucleocapsid transcripts in circulating blood cells from patients with paget's disease. J. Bone. Miner. Res., 11:1602-1607.

Reed, I. J. and Muench, J. (1938): A simple method of estimating fifty percents. Am. J. Hyg., 27:493-497.

Richard B. F. and Shelly L. V. (1998): Canine infectious tracheobronchitis Infectious diseases of dog \& cat. Second Edition W.B. Saunders company- A division of Harcourt Brace and company Philadelphia, London, Toronto, Montreal, Sydney, Tokyo. pp. 33-38.

Ronald, W. E. (1999): Combined vaccines, development clinical research and approval. Humana press Totowa, New Jersey.

Ruth, D. T. and Emary, J. B. (1981): Clinical trial of a modified live parvovirus vaccine for dogs. Vet. Med. Small Clinic., 76 (6): 830-832.

Salama, Z. T.; Aly, N. I.; Guirguis W. I. and Khodeir, M. H. (2003): Modification of the inactivated trivalent vaccine (rabies; canine distemper and canine parvo) used for dogs to iprove its immunogenecity. J. Egypt Vet. Med. Assoc., 63 (2): 137-146.

Saleh, A. A.; El-Galad, S. B.; Khodier, M. K. and Azab, A. M. (2002): Trivalent inactivated vaccine for dogs (rabies, canine distemper and canine parvo). J. Egypt. Vet. Med. Assoc., 62, (2): 209-222.
Sashi, B. M. and Dutla S. (1981): Veterinary microbiology, LEA Febigen Philadelphia. pp. 215-217.

Sikes, R. K.; Peacock, G.V.; Acha, P. N.; Arko, R. J. and Dierks, R. (1971): Rabies vaccines: Duration of immunity study in dogs. J. Am. Vet. Med. Assoc., 159: 1491-1499.

Smith, K. M. and Lauffer, M. (1962): Advances in virus research. Vol.9 pp.285.Achademic press Inc. Publishers New York London.

Sprino, P. J. and Harris, L. L. (1983): Serological interference study of a canine parvovirus, distemper, hepatitis, parainfluenza and L.canicola-interohaemorrhagiae. Vet. Med. Small Anim. Clinic., 78 (3): 337-339.

Stephenson, J. R. (2001): Genetically modified viruses: vaccines by design Currpharm Biotechnol., 2 (1): 47-76.

Tizard, I. R. (2000): Veterinary Immunology: An introduction. Saunders Company.

Trimarchi, C. V.; Rudd, R. D. and Safford, M. (1996): An in vitro virus neutralization test for rabies antibody in laboratory diagnosis of rabies, $4^{\text {th }}$ ed. WHO, Geneva. pp. 193-198.

Weichselbaum, T. E. (1946): An accurate and rapid method of the determination of protein in small amounts of blood serum and plasma. Am. J. Clin. Pathol., 16: 40-49.

Wilbur, L. A. and Aubert, M. F. (1996): In Laboratory techniques in rabies $4^{\text {th }}$ World health organization, 360-368. Williams, S. E. and Barker, I. K. (2001): Infectious diseases of wild mamales. $3^{\text {rd }}$ ed., Manson publishing. Vet. Press., 3-30. 